\title{
Physical activity in older individuals: scientific evidence
}

\author{
L Capranica*, A Tessitore, C Cortis, M F Piacentini, R De Pero, C Pesce \\ From de Senectute: Age and Health Forum \\ Catanzaro, Italy. 5-7 December 2009
}

Scientific evidence indicates that regular physical activity slows the rate of decline of most physiological agerelated parameters associated with health, fitness and quality of life [1]. Senior athletes provide an ideal model for successful aging. Although most of the information derives from individual closed-skill sports, little information is available regarding the motivation to sport participation and dietary and training regimens of senior athletes who might be at risk of incorrect training schedules or nutritional patterns. More recent studies focused on open-skill sports, which require aerobic and anaerobic energy productions, various exercises, cognitive functions, technical capabilities, and inter-individual interactions to cope with the playing environment.

Findings suggest that older athletes maintain good anaerobic and aerobic capacities [2,3], coordination capabilities [4], and attentional skills that outweigh agerelated deficits [5].

Furthermore, older athletes competing at a local level are less supported by self-determination as compared to age-matched athletes competing at national or international levels [6]. Moreover, senior competitions elicit high physiological responses, which represent a potential danger when no medical approval is obtained before starting the program [1,2]. Furthermore, older athletes undergoing improper diet regimens show amplified subjective perception of training intensity, attributable to their feelings rather than training parameters per se [5].

Published: 19 May 2010

\section{References}

1. Spirduso WW, Francis KL, MacRae PG: Physical dimensions of aging. Human Kinetics 2005.

Department of Human Movement and Sport Sciences, University of Rome Foro Italico, Rome, Italy
2. Tessitore A, et al: Fitness Profile, Heart Rate and Match Analysis in Older Soccer Players. Ergonomics. 2005, 48:1365-1377.

3. Tessitore A, et al: Aerobic-Anaerobic Profiles, Heart Rate and Match Analysis in OldBasketball Players. Gerontology. 2006, 52:214-222.

4. Cortis $C$, et al: Inter-limb Coordination, Strength, and Jump Performances Following a Senior Basketball Match. Contemporary Sport, Leisure and Ergonomics RoutledgeT. Reilly and G. Atkinson 2009, 353-367.

5. Pesce C: Preservation of visual attention in older expert orienteers at rest and under physical effort. Journal of Sport and Exercise Psychology. 2007, 29, 1:78-99.

6. De Pero R, et al: Motivation for Sport Participation in Italian Older Athletes: The role of Age, Gender, and Competition Level. Sport Sciences for Healthln press.

7. Piacentini MF, et al: Effects of the Zone-diet on training parameters in recreational master athletes. Contemporary Sport, Leisure and Ergonomics. RoutledgeT. Reilly and G. Atkinson 2009, 227-242.

doi:10.1186/1471-2318-10-S1-L33

Cite this article as: Capranica et al:: Physical activity in older individuals: scientific evidence. BMC Geriatrics 2010 10(Suppl 1):L33.

Submit your next manuscript to BioMed Central and take full advantage of:

- Convenient online submission

- Thorough peer review

- No space constraints or color figure charges

- Immediate publication on acceptance

- Inclusion in PubMled, CAS, Scopus and Google Scholar

- Research which is freely available for redistribution

Submit your manuscript at www.biomedcentral.com/submit
C Biomed Central 